\title{
Dukungan Teknologi Pada Integrasi Tanaman Hortikultura-Ternak Sapi Untuk Pengembangan Agribisnis Yang Berkelanjutan
}

\author{
Ivan Sujana $^{1)}$, Gusti Hardiansyah ${ }^{2)}$, Sarma Siahaan ${ }^{3)}$ \\ ${ }^{1)}$ Program Studi Teknik Industri, Fakultas Teknik, \\ ${ }^{2,3)}$ Program Studi Kehutanan, Fakultas Kehutanan, \\ Universitas Tanjungpura Pontianak \\ e-mail : : ivan_sujana30@yahoo.com
}

\begin{abstract}
Konsep pertanian terpadu yang melibatkan tanaman dan ternak sudah lama diterapkan oleh petani di Indonesia, namun penerapannya masih secara tradisional, tanpa memperhitungkan dari aspek secara finansial maupun dalam konteks pelestarian lingkungan hidup. Konsep sistem tanaman-ternak dilakukan dengan mempertimbangkan aspek-aspek keberlanjutan (sustainable) yang ramah lingkungan (environmentally tolerable), secara sosial diterima masyarakat (socially acceptable) dan secara ekonomi layak (economically feasible). Pendekatan yang dilakukan adalah penggunaan input dari luar yang rendah yang dikenal sebagai LEISA (low external input sustainable agriculture). Adanya dukungan teknologi dalam pendekatan LEISA untuk integrasi usahatani tanaman hortikultura-ternak diharapkan dapat mengembangkan agribisnis yang berkelanjutan dan menciptakan lapangan kerja yang bersumber pada usaha dengan memanfaatkan sumberdaya lokal khususnya limbah peternakan dan pertanian secara lebih efisien. Limbah kotoran ternak sapi dapat diolah menjadi energi dan pupuk organik sehingga dapat mendukung usahatani tanaman hortikultura. Sedangkan limbah usahatani tanaman hortikultura dapat diolah menjadi sumber pakan ternak bagi peternakan sapi. Apabila proses integrasi tanaman hortikultura dan ternak sapi dapat berhasil dengan baik, tidak mustahil akan terjadi peningkatan produksi dan produktivitas, yang pada gilirannya akan tercapai pengembangan agribisnis yang berkelanjutan.
\end{abstract}

\section{Keywords-Limbah, Biogas, Pakan Ternak}

\section{Pendahuluan}

\section{A. Analisis Situasi}

Masyarakat Indonesia yang berjumlah lebih dari 200 juta jiwa tentunya semakin banyak membutuhkan protein, baik dari protein hewani maupun nabati. Sumber protein hewani yang berasal dari ternak ruminansia salah satunya adalah daging sapi. Semakin bertambahnya jumlah penduduk dapat diartikan sebagai peningkatan permintaan daging sapi sebagai sumber protein, akan tetapi untuk memenuhi seluruh kebutuhan daging sapi tersebut, sebagian lagi masih diimpor dari negara tetangga. Sehingga upaya pengembangan populasi dan produktivitas ternak sapi potong harus mampu mengimbangi kecepatan bertambahnya konsumsi daging tersebut.

Berdasarkan hasil pencacahan lengkap ST2013, diperoleh populasi sapi dan kerbau di Provinsi Kalimantan Barat pada kondisi tanggal 1 Mei 2013 sebanyak 142.618 ekor. Selama periode 1 Juni 2011 sampai dengan 1 Mei 2013, populasi sapi dan kerbau mengalami penurunan sebanyak 14.095 ekor dari 156.713 ekor hasil Pendataan Sapi Potong, Sapi Perah, dan Kerbau (PSPK) 2011 (kondisi tanggal 1 Juni 2011) menjadi 142.618 ekor dari ST2013 (kondisi tanggal 1 Mei 2013). Berdasarkan hasil ST2013 apabila dirinci menurut wilayah, tiga kabupaten yang memiliki sapi dan kerbau paling banyak adalah Kabupaten Ketapang dengan jumlah populasi sebanyak 30.573 ekor, kemudian Kabupaten Kubu Raya 13.721 ekor, dan Kabupaten Sekadau 11.433 ekor. Sementara itu, kabupaten yang memiliki sapi dan kerbau paling sedikit adalah Kota Pontianak dengan jumlah populasi sebanyak 4.005 ekor.

Ternak sapi potong yang berkembang di Kota Pontianak saat ini sebagian besar merupakan peternakan rakyat yang melakukan sistem budidaya tradisional bersifat sosial, nilai efektifitas dan efisiensi rendah serta serapan informasi teknologi dan inovasi yang lambat. Hal ini menjadi penyebab perkembangan populasi sapi potong yang terhitung sangat rendah. Salah satu kendala yang sering dijumpai terkait rendahnya produktivitas ternak sapi di Kota Pontianak karena berkaitan dengan ketersediaan pakan yang berfluktuasi. Di lain pihak, potensi bahan baku pakan lokal seperti limbah pertanian hortikultura yang ada di wilayah Kota Pontanak belum dimanfaatkan secara optimal.

Hasil samping tanaman pertanian hortikultura sebenarnya bukan limbah, tetapi sumberdaya yang sangat potensial untuk dikembangkan. Kelemahan yang ada pada potensi tersebut adalah ketidaklaziman untuk digunakan sebagai bahan pakan oleh masyarakat dan memiliki kandungan nutrisi rendah (protein dan energi). Upaya yang dapat dilakukan untuk mengoptimalkan pemanfaatan limbah pertanian hortikultura sebagai pakan ternak dapat dilakukan melalui peningkatan kualitas limbah tersebut melalui teknologi fermentasi, suplementasi atau pembuatan pakan lengkap (complete 
feed). Pada Gambar 1 akan memperjelas upaya mengubah limbah (waste) menjadi sumber daya (resources).

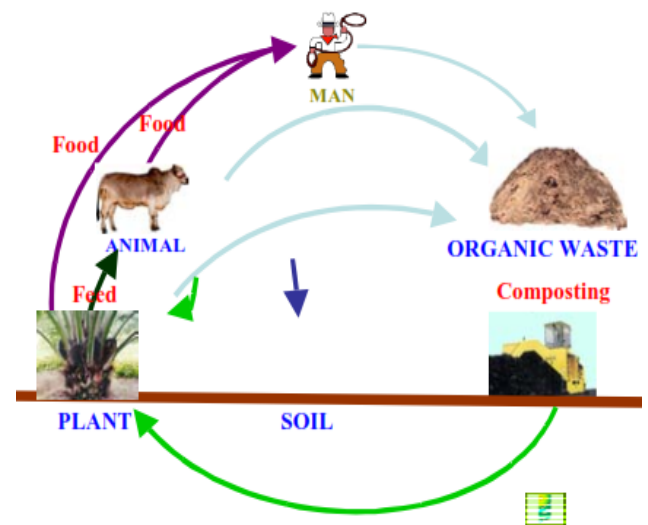

Gambar 1. Pendekatan LEISA, mengubah limbah menjadi sumber daya

Selain itu, penggunaan pupuk anorganik secara berlebihan pada tanaman holtikultura dalam waktu yang lama dapat menyebabkan kondisi fisik tanah semakin buruk. Sehingga pemberian bahan organik berupa pupuk kandang pada tanaman holtikultura merupakan salah satu alternatif yang baik. Pupuk organik yang berasal dari kotoran ternak sapi dapat memperbaiki sifat fisik tanah karena perbaikan aerasi tanah dan peningkatan ketersediaan unsur-unsur hara yang terikat dengan koloid tanah, sehingga juga akan memperbaiki nisbah karbon terhadap nitrogen dalam tanah. Membaiknya kondisi fisik tanah dapat diharapkan produksi tanaman pertanian hortikultura per satuan luas juga akan meningkat, dan pada saatnya nanti pendapatan petani juga meningkat.

Pemanfaatan limbah, baik itu limbah peternakan (kotoran ternak) maupun limbah pertanian hortikultura merupakan salah satu alternatif yang sangat tepat dalam pengembangan agribisnis yang berkelanjutan, Pemanfaatan limbah kotoran ternak sebagai sumber energi (biogas), tidak mengurangi jumlah pupuk organik yang bersumber dari kotoran ternak. Hal ini karena pada pembuatan biogas kotoran ternak yang sudah diproses dikembalikan ke kondisi semula, yang diambil hanya gas metana $\left(\mathrm{CH}^{4}\right)$ yang digunakan sebagai bahan bakar. Kotoran ternak yang sudah diproses pada pembuatan biogas dipindahkan ke tempat lebih kering, dan bila sudah kering dapat disimpan dalam karung untuk penggunaan selanjutnya sebagai pupuk yang dibutuhkan oleh pertanian hortikultura. Sedangkan limbah pertanian hortikultura dapat diolah menjadi pakan ternak, sehingga dapat mengatasi ketersediaan pakan ternak yang selalu berfluktuasi.

Masalah-masalah tersebut harus diatasi melalui pemanfaatan teknologi dari berbagai disiplin ilmu. Artikel ini akan membahas integrasi ternak dengan tanaman pertanian hortikultura dengan pola zero waste sebagai upaya untuk mewujudkan agribisnis yang berkelanjutan.

\section{B. Kajian Pustaka}

\section{a. Limbah Kotoran Ternak}

Pemanfaatan kotoran ternak sebagai sumber pupuk organik sangat mendukung usaha pertanian tanaman sayuran. Dari sekian banyak kotoran ternak yang terdapat didaerah sentra produksi ternak banyak yang belum dimanfaatkan secara optimal, sebagian di antaranya terbuang begitu saja, sehingga se-ring merusak lingkungan yang akibatnya akan menghasilkan bau yang tidak sedap. Satu ekor sapi dewasa dapat menghasilkan 23,59 kg kotoran tiap harinya. Pupuk organik yang berasal dari kotoran ternak dapat menghasilkan beberapa unsur hara yang sangat dibutuhkan tanaman, seperti terlihat pada Tabel 1. Di samping menghasilkan unsur hara makro, pupuk kandang juga menghasilkan sejumlah unsur hara mikro, seperti $\mathrm{Fe}, \mathrm{Zn}, \mathrm{Bo}, \mathrm{Mn}, \mathrm{Cu}$, dan Mo. Jadi dapat dikatakan bahwa, pupuk kandang ini dapat dianggap sebagai pupuk alternatif untuk mempertahankan produksi tanaman.

Tabel 1. Kandungan Unsur Hara pada Pupuk Kandang Dari Beberapa Ternak

\begin{tabular}{lccc}
\hline \multirow{2}{*}{ Jenis Ternak } & \multicolumn{3}{c}{ Unsur Hara } \\
\cline { 2 - 4 } & $\mathbf{N}$ & $\mathbf{P}$ & $\mathbf{K}$ \\
\hline Sapi perah & 22,0 & 2,6 & 13,7 \\
\hline Sapi potong & 26,2 & 4,5 & 13,0 \\
\hline Domba & 50,6 & 6,7 & 39,7 \\
\hline Unggas & 65,8 & 13,7 & 12,8 \\
\hline Sumber: http://www.disnak.jabarprov.go.id/data/arsip/.
\end{tabular}

\section{b. Biogas Sebagai Sumber Energi Alternatif}

Biogas adalah gas yang mudah terbakar (flammable) yang dihasilkan dari proses fermentasi bahan-bahan organik oleh bakteri-bakteri anaerob yaitu bakteri yang hidup dalam kondisi kedap udara (http://www.majarikanayakan.com/). Pada umumnya semua jenis bahan organik bisa diproses untuk menghasilkan biogas, namun demikian hanya bahan organik (padat, cair) homogen seperti kotoran dan urine (air kencing) hewan ternak yang cocok untuk sistem biogas sederhana.

Jenis bahan organik yang diproses sangat mempengaruhi produktivitas sistem biogas di samping parameter-parameter lain seperti temperatur digester, pH, tekanan, dan kelembaban udara. Salah satu cara menentukan bahan organik yang sesuai untuk menjadi bahan masukan sistem biogas adalah dengan mengetahui perbandingan karbon $(\mathrm{C})$ dan nitrogen $(\mathrm{N})$ atau disebut rasio $\mathrm{C} / \mathrm{N}$. Beberapa percobaan yang telah dilakukan oleh ISAT menunjukkan bahwa aktivitas metabolisme dari bakteri methanogenik akan optimal pada nilai rasio $\begin{array}{llll}\text { perbandungan } & \mathrm{C} / \mathrm{N} & \text { sekitar } & 8-20\end{array}$ (http://www.petra.ac.id/science/applied_technology/ biogas98/biogas.htm).

Bahan organik dimasukkan ke dalam digester sehingga bakteri anaerob akan membusukkan bahasan organik tersebut yang kemudian menghasilkan gas (disebut biogas). Biogas yang telah berkumpul di dalam digester selanjutnya dialirkan melalui pipa penyalur gas 
menuju tabung penyimpan gas atau langsung digunakan. Nilai kalori dari 1 meter kubik biogas sekitar 6.000 watt jam yang setara dengan setengah liter minyak diesel. Oleh karena itu, biogas sangat cocok digunakan sebagai bahan bakar alternatif yang ramah lingkungan.

Di samping itu, dari proses produksi biogas akan dihasilkan sisa kotoran ternak yang dapat langsung dipergunakan sebagai pupuk organik pada tanaman/ budidaya pertanian. Limbah biogas, yaitu kotoran ternak yang telah hilang gasnya (slurry) merupakan pupuk organik yang sangat kaya akan unsur-unsur yang dibutuhkan oleh tanaman. Bahkan, unsur-unsur tertentu seperti protein, selulose, lignin dan lain-lain tidak dapat digantikan oleh pupuk kimia. Komposisi gas yang terdapat di dalam Biogas dapat dilihat pada Tabel 2 berikut.

Tabel 2. Komposisi Gas yang terdapat dalam Biogas

\begin{tabular}{lc}
\multicolumn{1}{c}{ Jenis Gas } & Volume $(\boldsymbol{\%})$ \\
\hline Metana $\left(\mathrm{CH}_{4}\right)$ & $40-70$ \\
\hline Karbondioksida $\left(\mathrm{CO}_{2}\right)$ & $30-60$ \\
\hline Hidrogen $\left(\mathrm{H}_{2}\right)$ & $0-1$ \\
\hline Hidrogen Sulfida $\left(\mathrm{H}_{2} \mathrm{~S}\right)$ & $0-3$ \\
\hline
\end{tabular}

Sumber: (http://www.energi.lipi.go.id)

Adapun cara pengoperasian reaktor biogas skala rumah tangga bagi peternak :

1) Buat campuran kotoran ternak dan air dengan perbandingan 1:1 (bahan biogas).

2) Masukkan bahan biogas ke dalam reaktor melalui tempat pengisian sebanyak 1000 liter, selanjutnya akan berlangsung proses produksi biogas ke dalam reaktor.

3) Setelah kurang lebih 10 hari reaktor gas (digester) akan terisi biogas, dan biogas sudah dapat digunakan sebagai bahan bakar, kompor biogas dapat dioperasikan.

4) Sekali-sekali reaktor biogas (digester) diaduk atau digoyangkan supaya terjadi penguraian yang sempurna dan gas yang terbentuk di bagian bawah naik ke atas, lakukan juga pada setiap pengisian bahan bakar.

5) Pengisian bahan biogas selanjutnya dapat dilakukan setiap hari, yaitu sebanyak \pm 40 liter setiap pagi dan sore. Sisa pengolahan bahan biogas berupa sludge (lumpur) secara otomatis akan keluar dari reaktor setiap kali dilakukan pengisian bahan biogas. Sisa hasil pengolahan bahan biogas tersebut dapat digunakan langsung sebagai pupuk organik, baik dalam keadaan basah maupun kering untuk kebutuhan pertanian atau perkebunan.

\section{c. Limbah Hortikultura Sebagai Pakan Ternak}

Pakan fermentasi merupakan pakan hewan ternak yang terbuat dari olahan limbah organik yang diberikan kepada hewan ternak setelah melalui tahap fermentasi. Diversifikasi pemanfaatan limbah yang berasal dari limbah pertanian menjadi pakan telah mendorong perkembangan agribisnis ternak ruminansia secara integratif dalam suatu sistem produksi terpadu dengan pola pertanian melalui daur ulang biomas yang ramah lingkungan atau dikenal "zero waste production system".

Beberapa keunggulan dalam memberikan pakan fermentasi kepada hewan ternak ruminansia meliputi :

1) Pakan dapat disimpan sesuai kebutuhan

2) Meningkatkan nafsu makan sehingga mempercepat pertumbuhan ternak

3) Daging hewan ternak menjadi rendah kolesterol dan tidak "prengus"

4) Kotoran hewan tidak menimbulkan bau/amoniak

5) Kotoran hewan berkualitas untuk dimanfaatkan menjadi pupuk

Pakan ternak fermentasi limbah pertanian merupakan solusi terbaik untuk mendorong peternakan di indonesia dan perlu untuk dikembang-kan lebih besar lagi, karena sektor ternak di dalam negeri jumlahnya masih sangat minim, sedangkan permintaan daging terus meningkat.

Teknik untuk memfermentasi limbah pertanian menjadi pakan ternak sapi secara umum dikelompokkan menjadi dua yaitu fermentasi kering dan basah. Biasanya fermentasi basah dapat diperoleh dari limbah perkebunan seperti, batang pisang (gedebog), batang jagung yang dipanen muda, kacang tanah, rumput dan limbah pertanian yang lainnya. Untuk mengolah limbah pertanian dari tanaman hortikultura dibutuhkan sentuhan teknologi fermentasi.

Teknologi/cara pembuatan pakan ternak dapat dilakukan melalui pengolahan dengan mesin-mesin skala kecil yang dapat dilaksanakan pada tingkat kelompok tani. Prosedur pembuatan pakan ternak yang menggunakan bahan baku limbah pertanian dan limbah agroindustri adalah sebagai berikut :

1) Bahan-bahan sumber serat dipotong-potong dengan alat pemotong (choper) dengan ukuran $0,5-1 \mathrm{~cm}$, kemudian dikeringkan dengan menggunakan pemanasan sinar matahari atau alat-alat pemanas sampai kadar air $10-12 \%$.

2) Bahan-bahan sumber energi dicampur dalam alat pencampur/mixer bersama dengan larutan molase sampai merata.

3) Seluruh bahan-bahan tersebut selanjutnya digiling dengan alat penggilingan (grinding) atau hamer mill dan ditambahkan urea, garam dapur, dan tepung tulang sampai ukuran partikelnya kecil-kecil dan tercampur secara merata atau homogen. Apabila telah tercampur, maka bahan-bahan tersebut dikemas dalam karung yang sudah disiapkan dengan ukuran berat sesuai dengan yang diinginkan.

\section{Tujuan Kegiatan}

Adapun tujuan yang dilakukan dari kegiatan ini adalah :

a. Memberi masukan kepada masyarakat tentang pemanfaatan limbah dari kotoran ternak dan limbah tanaman hortikultura bagi kepentingan masyarakat petani dan peternak. 
b. Memberikan informasi kepada masyarakat tentang aspek sosio-kultural dari penerapan teknologi biogas dan pengolahan pakan ternak dalam rangka perintisan wirausaha baru.

c. Mengkaji prospek penerapan teknologi biogas dan pengolahan pakan ternak di Kelurahan Siantan Hulu, Kecamatan Pontianak Utara terkait dengan aspek community development untuk pengem-bangan agribisnis yang berkelanjutan.

\section{Manfaat Kegiatan}

Manfaat yang diharapkan dari kegiatan ini antara lain sebagai berikut :

a. Hasil dari kegiatan yang dilakukan diharapkan dapat menjadi rintisan kegiatan sistem pengelolaan limbah kotoran ternak dan limbah tanaman hortikultura menjadi limbah yang berdaya guna.

b. Program kegiatan yang dijalankan dapat dijadikan sebagai media penghubung antar petani dan peternak dalam pengelolaan dan pemanfaatan dari masingmasing limbah yang dihasilkan sehingga dapat terbentuk atmosfir sosio kultural yang harmonis dan berkesinambungan.

c. Memotivasi masyarakat petani dan peternak yang ada di Kelurahan Siantan Hulu, Kecamatan Pontianak Utara untuk bisa merintis wirausaha baru di bidang pengelolaan dan pemanfaatan limbah mereka.

d. Meningkatkan pendapatan masyarakat petani dan peternak sapi di Kelurahan Siantan Hulu, Kecamatan Pontianak Utara sehingga pengem-bangan agribisnis yang berkelanjutan melalui integrasi tanaman hortikultura-ternak sapi dapat tercapai.

\section{Metode Pelaksanaan}

1. Khalayak Sasaran

Sasaran penyuluhan dan pemberian pelatihan penerapan teknologi pengelolaan dan pemanfaatan limbah ini adalah peternak sapi pada Kelompok Tani Pangeran Dua dan petani hortikultura pada Kelompok Tani Pangeran Satu di Kelurahan Siantan Hulu, Kecamatan Pontianak Utara. Hal ini dikarenakan hampir sebagian besar penduduk di Kelurahan Siantan Hulu, Kecamatan Pontianak Uatara bermata pencaharian sebagai peternak dan petani hortikultura. Pemilihan sasaran kegiatan ini diambil dengan pertimbangan mereka akan dapat memberikan informasi tentang penerapan teknologi yang mereka peroleh kepada keluarga, tetangga maupun kelompok tani lainnya yang ada di sekitar Kecamatan Pontianak Utara.

Kegiatan penerapan ipteks ini juga bekerja sama dengan masyarakat di Kelurahan Sinatan Hulu, selain itu, pada pelaksanaannya juga berkoordinasi dengan pihak Kelurahan dan Dinas Peternakan Kota Pontianak.

\section{Metode Kegiatan}

Metode kegiatan ini meliputi ceramah, diskusiinformasi, workshop, dan disseminasi terbatas. Secara lebih rinci metode yang digunakan adalah :

a. Menjelaskan kepada peserta pelatihan mengenai cara mengelola limbah ternak sapi menjadi biogas dan cara mengelola limbah tanaman hortikultura menjadi pakan ternak.

b. Diskusi-informasi membahas cara mengatasi kesulitan dalam memulai pembuatan biogas dan juga pakan ternak serta menjelaskan cara mengatasinya sehingga dapat dihasilkan biogas yang ramah lingkungan dan pakan ternak yang baik.

c. Para peserta pelatihan diberi kesempatan untuk melakukan sendiri proses pembuatan biogas dan juga pakan ternak menggunakan teknologi yang telah dihibahkan kepada Kelompok Tani Pangeran Dua (peternak sapi) dan Kelompok Tani Pangeran Satu (petani hortikultura).

d. Hasil uji coba selanjutnya dipresentasikan untuk bahan diskusi dan untuk selanjutnya siap didisseminasikan kepada masyarakat lainnya.

e. Sebagai tindak lanjut dari kegiatan ini diharapkan para petani dan peternak di Kelurahan Siantan Hulu, Kecamatan Pontianak Utara dapat membentuk kelompok usaha pembuatan biogas dan juga pakan ternak. Hal ini dimaksudkan untuk perintisan wirausaha dan mereduksi masalah sosio-kultural yang ditimbulkan baik oleh limbah ternak sapi maupun limbah tanaman hortikultura.

3. Tahapan Kegiatan

Kegiatan penerapan Iptek bagi masyarakat ini berupa rancang bangun alat/mesin dan aplikasi teknologi yang diawali dengan melakukan observasi dan analisa terhadap permasalahan mendasar yang dihadapi oleh peternak sapi dan petani hortikultura. Observasi terhadap peternak sapi dilakukan pada anggota Kelompok Tani Pangeran Dua (peternak sapi) dan terhadap petani hortikultura dilakukan pada Kelompok Tani Pangeran Satu (petani hortikultura).

Berdasarkan hasil obervasi dan analisa yang telah dilakukan, hasilnya perlu adanya teknologi aplikatif yang sesuai dengan agroekosistem untuk pengolahan limbah yang berasal dari kedua kelompok tani tersebut, untuk dapat saling dimanfaatkan oleh kedua belah pihak, sehingga dapat menunjang usaha agribisnis mereka secara berkelanjutan. Langkah-langkah kegiatan yang dilaksanakan selama penerapan Iptek bagi masyarakat tersebut seperti terlihat pada Gambar 2 berikut :

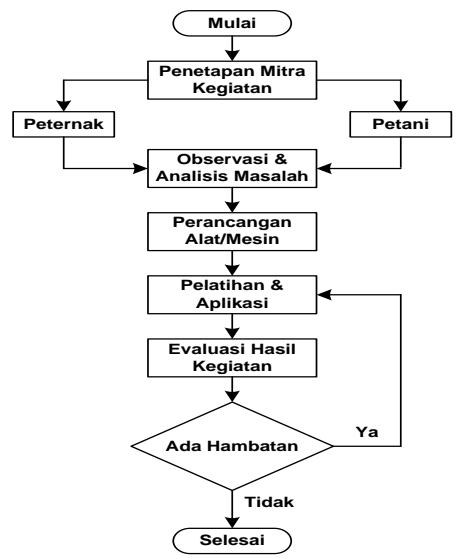

Gambar 2. Tahapan Kegiatan 


\section{Hasil Dan Pembahasan}

Sesuai dengan jadwal, metode dan rencana pelaksanaan kegiatan yang sudah ditentukan maka urutan kegiatan dan hasil yang diperoleh dalam kegiatan ini adalah sebagai berikut :

1. Penyampaian Materi Mengenai Biogas dan Pakan Ternak.

Beberapa pengetahuan yang disampaikan diantaranya adalah : (a) biogas dan apa yang terkandung di dalamnya sehingga dapat dimanfaatkan sebagai sumber energi alternatif; (b) mekanisme reaksi yang terjadi di dalam pembuatan biogas dalam rangka mengetahui bagaimana caranya agar biogas dapat terbentuk; (c) kotoran ternak dan unsur apa saja yang terkandung di dalamnya sebagai syarat pembuatan biogas; (d) konversi banyaknya energi yang dihasilkan biogas setiap liternya; (e) pakan ternak ruminansia dan apa saja komposisi bahan yang diperlukan dalam pembuatan pakan ternak; (f) tahapan proses pengolahan dalam pembuatan pakan ternak dan mekanisme reaksi yang terjadi dalam proses fermentasinya; (g) mekanisme yang diperlukan dalam pembuatan, penggunaan dan perawatan instalasi biogas dan mesin pencacah pakan ternak; (h) penanganan limbah hasil pengolahan biogas dan limbah tanaman hortikultura ditinjau dari apek sosiokulturalnya.

2. Pengamatan Kegiatan Aplikasi Teknologi di Lapangan Oleh Peserta.

Para peserta yang telah mendapatkan materi pengetahuan tentang biogas dan pakan ternak ruminansia sert aspek sosiokulturalnya, selanjutnya mencoba melihat bagaimana mekanisme pembuatan instalasi biogas dan pakan ternak di lapangan sesungguhnya. Kegiatan ini bertujuan untuk menjelaskan kepada peserta tentang materi yang sudah diterima dan membandingkannya dengan kondisi lapangan yang sesungguhnya. Kegiatan ini dilanjutkan dengan pengamatan, pengidentifikasian dan penyusunan data-data pendukung yang diperlukan peserta. Data-data ini yang akan dijadikan bahan peserta dalam kegiatan diskusi dengan Tim Pengabdi guna memantapkan penguasaan materi yang telah diberikan.

\section{Kegiatan Diskusi Dengan Peserta}

Sebagai akhir dari kegiatan yang dilakukan oleh peserta adalah diskusimengenai materi pemanfaatan limbah kotoran ternak menjadi biogas sebagai sumber bahan bakar alternatif dan pemanfaatan limbah tanaman hortikultura menjadi pakan ternak beserta aspek sosio kulturalnya. Setiap komponen materi yang telah diberikan didiskusikan bersama Tim Pengabdi.

Kegiatan pengabdian kepada masyarakat mengenai aplikasi teknologi untuk pemanfaatan limbah kotoran ternak menjadi biogas dan pemanfaatan limbah tanaman hortikultura menjadi pakan ternak di Kelurahan Siantan Hulu, Kecamatan Pontianak Utara dilaksanakan pada tanggal 5 Agustus 2016. Jumlah peserta yang mengikuti kegiatan yaitu 21 orang dari 30 orang yang diundang oleh Tim Pengabdi. Para peserta merupakan penduduk Desa Parit Pangeran, Kelurahan Siantan Hulu yang berprofesi sebagai petani hortikultura dan peternak sapi.
Materi yang disampaikan terdiri dari: (1) pemanfaatan limbah kotoran ternak sapi menjadi biogas energi alternatif yang ramah lingkungan; (2) pemanfaatan limbah tanaman hortikultura menjadi pakan ternak ruminansia. Pemberian materi dilakukan dalam bentuk ceramah, dilanjutkan dengan pengamatan dan uji coba lapangan oleh peserta serta diakhiri serah terima unit instalasi biogas dan mesin pencacah pakan ternak kepada masyarakat yang diwakili oleh Ketua Kelompok Tani Pangeran Dua (peternak sapi) dan Ketua Kelompok Tani Pengeran Satu (petani hortikultura). Pada waktu diskusi berlangsung terlihat bahwa penguasaan peserta mengenai pengelolaan limbah kotoran ternak menjadi biogas maupun pengelolaan limbah hortikultura menjadi pakan ternak masih relatif rendah. Tim pengabdi selain memberikan materi tentang bagaimana cara memanfaatkan limbah kotoran ternak menjadi biogas dan limbah tanaman hortikultura menjadi pakan ternak, Tim juga menjelaskan kemungkinan-kemungkinan lain yang bisa dikem bangkan melalui pemanfaatan limbah tersebut serta bagaimana cara mengelolanya sehingga dapat meningkatkan pendapatan rumah tangga. Para peserta semakin menyadari bahwa pemanfaatan dan pengelolaan limbah dari hasil kegiatan usaha mereka jika dikelola dan dilakukan dengan sungguh-sungguh akan berdampak positif bagi perekonomian mereka.

\section{A. Karya Utama}

Karya utama dari kegiatan ini adalah suatu teknologi berupa unit rangkaian instalasi biogas untuk pengolahan limbah kotoran ternak sapi menjadi biogas dan pupuk organik bagi peternak sapi dan mesin pencacah pakan ternak untuk pengolahan limbah tanaman hortikultura menjadi pakan ternak ruminansia bagi petani hortikultura. Hal yang utama dalam kegiatan pengabdian kepada masyarakat ini adalah transfer iptek kepada masyarakat peternak sapi dan petani hortikultura dalam pengolahan dan pengelolaan limbah yang mereka miliki sehingga menjadi produk yang memiliki nilai tambah untuk meningkatkan perekonomian para peternak sapi dan petani hortikultura. Selain itu juga diharapkan dengan adanya kegiatan ini akan dapat terwujud suatu integrasi antara petani tanaman hortikultura dan peternak sapi sehingga pengembangan agribisnis yang berkelanjutan dapat terlaksana.

\section{B. HASIL KARYA}

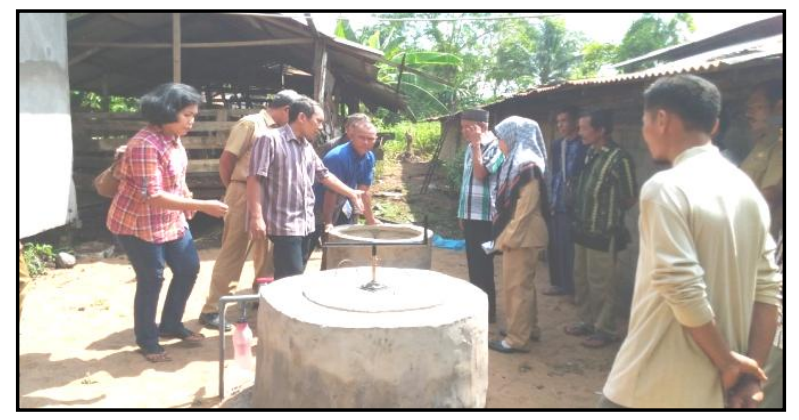

Gambar 3. Unit Instalasi Biogas 


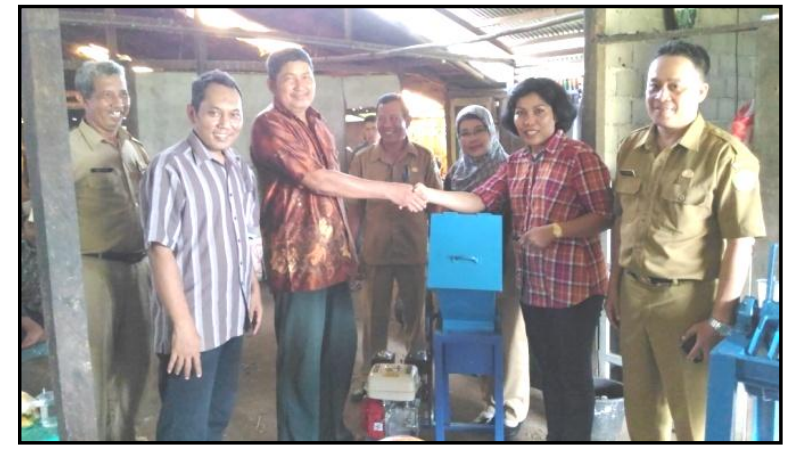

Gambar 4. Mesin Pencacah Pakan Ternak

\section{Kesimpulan}

Berdasarkan hasil dari proses kegiatan pengab-dian masyarakat ini diperoleh hasil sebagai berikut :

1. Masyarakat petani hortikultura dan atau peternak sapi di Kelurahan Siantan Hulu, Kecamatan Pontianak Utara menjadi paham dan mengetahui bagaimana pemanfaatan dari limbah kotoran ternak menjadi biogas dan pupuk organik serta pemanfaatan limbah hortikultura menjadi pakan ternak ruminansia.

2. Aspek sosio-kultural dari penerapan teknologi biogas dan teknologi pakan ternak dalam rangka perintisan wirausaha baru telah dipahami dengan baik oleh masyarakat petani hortikultura dan peternak sapi yang ada di Kelurahan Siantan Hulu, Kecamatan Pontianak Utara.

3. Masyarakat petani hortikultura dan peternak sapi mengetahui prospek apa saja yang dapat dikembangkan berkaitan dengan penerapan teknologi biogas dan teknologi pakan ternak dalam rangka community development dan pengembangan agribisnis yang berkelanjutan.

\section{Referensi}

[1] Aysia, Debora A.Y., S. Panjaitan, T.W., Adiputra, Y.R., 2012. "Pembuatan Biogas dari Kotoran Sapi dengan Metode Taguchi", Prosiding Seminar Nasional Manajemen Teknologi XV Program Studi MMT-ITS, Surabaya 4 Pebruari 2012.

[2] Direktorat Penelitian dan Pengabdian Kepada Masyarakat, (2013). Panduan Penelitian dan Pengabdian Kepada Masyarakat di Perguruan Tinggi Edisi IX, Direktorat Jenderal Pendidikan Tinggi, Kementerian Pendidikan dan Kebudayaan.

[3] Moch. Romli., Basuki, Teger., dkk., 2012. "Sistem Pertanian Terpadu Tebu-Ternak Mendukung Swasembada Gula dan Daging". http://pkpp.ristek.go.id/. Diakses 8 April 2015.

[4] Putro, Sartono., 2007. "Penerapan Instalasi Sederhana Pengolahan Kotoran Sapi Menjadi Energi Biogas Di Desa Sugihan Kecamatan Bendosari Kabupaten Sukoharjo". WARTA, Vol .10, No. 2, September 2007: 178 - 188

[5] Rahayu, S., Purwaningsih, D., Pujianto., 2009. "Pemanfaatan Kotoran Ternak Sapi Sebagai Sumber
Energi Alternatif Ramah Lingkungan Beserpa Aspek Sosio Kulturalnya”, FISE Universitas Negeri Yogyakarta.

[6] Siregar, Yosi Kumala Santi., 2009. “Analisis Kelayakan Pengusahaan Sapi Perah dan Pemanfaatan Limbah untuk Menghasilkan Biogas dan Pupuk Kompos". Departemen Agribisnis fakultas Manajemen IPB.

[7] Sugama, I Nyoman., Budiari, Ni Luh Gede., 2012. "Pemanfaatan Jerami Padi Sebagai Pakan Alternatif Untuk Sapi Bali Dara". Balai Pengkajian Teknologi Pertanian Bali.

[8] http://download.portalgaruda.org/. Diakses 8 April 2015

[9] Widyastuti, F.R., Purwanto., Hadiyanto., 2013. "Upaya Pengelolaan Lingkungan Usaha Peternakan Sapi di Kawasan Usahatani Terpadu Bangka Botanical Garden Pangkalpinang", Prosiding Seminar Nasional Pengelolaan Sumber Daya Alam dan Lingkungan.

[10] Widayanto, Jujur S., 2012. "Rancang Bangun Mesin Pencacah Enceng Gondok Untuk Pembuatan Biogas". Laporan Tugas Akhir, Prodi D3 Teknik Mesin, Fakultas Teknik, UNDIP Semarang. http://eprints.undip.ac.id/ Diakses 1 April 2015

\section{Biography}

Ivan Sujana, lahir di Singkawang, 30 Desember 1970. Tahun 1995 dia memperoleh gelar Sarjana Teknik (ST) dari Universitas Jenderal Achmad Yani dengan bidang keahlian Teknik dan Manajemen Industri. Kemudian gelar Magister Teknik (MT) Teknik dan Manajemen Industri di peroleh dari Institut Teknologi Bandung (ITB) pada tahun 2004. Sejak tahun 1999 sampai dengan sekarang dia merupakan dosen tetap pada Program Studi Teknik Industri di Fakultas Teknik Universitas Tanjungpura

Gusti Hardiansyah, lahir di Pontianak, 30 November 1967. Tahun 1991 dia memperoleh gelar Sarjana Kehutanan (Ir) dari Universitan Tanjungpura dengan bidang keahlian Manajemen Hutan. Kemudian gelar Master (M.Sc) pada bidang studi Forest Economics diperoleh dari Washington State University pada tahun 1996. Pada tahun 2003 memperoleh gelar Doktor (Dr) di bidang Pengelolaan Sumberdaya Alam \& Lingkungan dari Institut Pertanian Bogor (IPB). Sejak tahun 1993 sampai dengan sekarang dia merupakan dosen tetap pada Program Studi Kehutanan di Fakultas Kehutanan Universitas Tanjungpura.(gusti.hardiansyah@gmail.com)

Sarma Siahaan, lahir di Balige, 20 September 1972. Tahun 1996 dia memperoleh gelar Sarjana (S.Si) dari Universitan Tanjungpura dengan bidang Matematika. Kemudian gelar Master (M.Si) pada bidang studi Pengelolaan Sumber Daya Alam dan Lingkungan (PSL) diperoleh dari Institut Teknologi Bandung pada tahun 2009. Sejak tahun 1999 sampai dengan sekarang dia merupakan dosen tetap pada Program Studi Kehutanan di Fakultas Kehutanan Universitas Tanjungpura. (sarmasiahaan@yahoo.com.) 